\title{
Analysis of the Influence of Product and promotion On Purchase Decisions on the Products of Micro, Small and Medium enterprises in the District Rengat
}

\author{
Hermanto $^{1^{*}}$, Roky Apriansyah ${ }^{2}$, Yudha Remofa ${ }^{3}$ \\ ${ }^{123}$ Dosen Sekolah Tinggi Ilmu Ekonomi Indragiri (STIE-I) Rengat. \\ * Corresponding author: \\ Email: hermanto@stieindragiri.ac.id
}

\begin{abstract}
.
This research was conducted on Micro, Small and Medium enterprises engaged in the business of Chips Onion/Banana Kecamatan Rengat. the purpose of this study to determine the effect of products and promotions partially and simultaneously on Purchase Decisions on the Products of Micro, Small and Medium enterprises in the District Rengat. The sample in this research is consumers who shop at the business Chips Onion/Banana Kecamatan Rengat as many as 99 Samples. The type of data used in this research is primary data in the form of quantitative data was done by distributing questionnaires messages to consumers who shop. Analysis tools that the authors use is Multiple Linear Regression Analysis with a quantitative approach with the help of SPSS Software Version 21. The results of the research can be concluded that: (1) the Product is partially significant effect on Purchase Decisions on SMES in the district Rengat. (2) the Promotion is partially significant effect on SMES in the district Rengat. (3) Products and Promotions simultaneously have a significant effect on Purchase Decisions on SMES in the district Rengat.
\end{abstract}

Keywords: Product, Promotion, Purchase Decision.

\section{INTRODUCTION}

Micro, small and medium enterprises (SMES) are businesses that deal on various business sectors, which touch the interests of the community. The emergence of the sector of Micro, Small, and Medium enterprises (SMES) bring a positive influence on the economy. Micro and small business is an informal business that began to appear to see the opportunities that exist around. Of course the business is a productive business which of course generates income for the entrepreneurs who founded the business. Such a response is shown by the success obtained and can survive.

According to Law No. 20 Year 2008 on Micro, Small and Medium-sized enterprises (SMES). Micro business is a productive business owned natural persons and/or entities individuals who meet the criteria of Micro enterprise as regulated in the Legislation. Small businesses are productive economic activities that stand alone, which done by individual or business entity that is not a subsidiary or is not a branch companies owned, controlled or being part either directly or indirectly from a medium

http://ijstm.inarah.co.id 
or large business that meets the criteria of a Small Business as referred to in the Legislation. Medium-sized businesses are productive economic activities that stand alone, which is carried out by an individual or business entity that is not a subsidiary or branch company owned, controlled or being part either directly or indirectly with a Small Business or a large business with the amount of net worth or results of annual sales as regulated in the Legislation.

The purchase decision according to [1] is a decision as the ownership of an action of two or more alternative options. One of the keys to success in Micro, Small and Medium Enterprises is in consumer purchasing decisions. Furthermore, [2] The level of consumer involvement in a purchase is influenced by a stimulus (stimulus). In other words, whether a person feels involved or not in a product is determined whether he feels important or not in making a product or service purchase decision. Therefore, it can be said that there are consumers who have high involvement in the purchase of a product or service, and there are also consumers who have low involvement in the purchase of a product or service.

Consumer purchasing decisions have several considerations, including decisions about the type of product, product form, brand, seller, number of products, purchase time and method of payment. The product purchased must be of high quality, consumers will feel the product is of quality if the product can meet the wants and needs as expected or exceed what is expected. Product quality is the ability of a product to carry out its functions including durability, reliability, accuracy, ease of operation and repair, as well as other valuable attributes [3]

Many factors influence purchasing decisions, such as products and promotions. Products are everything that can be offered to the market for attention, possession, use, or consumption that can satisfy needs and wants [4]. Promotion is a process of communicating information between sellers and potential buyers or other people in the channel to influence consumer attitudes and behavior [5].

District Rengat a lot of Micro, Small, Medium, better than generating products and services. Businesses which run diverse, from food, drink or goods kerajaninan tangible. In a study conducted at this time only focused on Businesses that produce products made by the businesses that exist in the community. Through the pre survey conducted by the researchers, that there are still businesses who had problems with the turnover that he received decreased. This will certainly affect the continuity of their business. Purchasing decisions which is becoming one of the determinants of business continuity of business is run, certainly will have great impact on the business. As a business should be able to increase the interest of the community to buy the products they sell, taking into account the tastes of consumers.

Businesses in influencing the purchase decision on consumer must consider the product they sell as well as how the promotion is done by him, the results of the pre survey is carried out still found products that have packaging as usual, in addition to promotions that do are still mediocre. Businesses in promoting their products to sell it 
to the market and put their products in the stalls and shops. In addition to the label of the product that they put on the packaging of the product is still too mediocre making it less attractive for consumers.

From the results of the pre survey is conducted by researchers of seven businesses above, that the number of consumers that exist in the year 2019 right now in this moment experiencing the decline, but in the previous year the number of consumer who shop on the business more than that. This is because the purchase decision on consumer decline.

\section{METHODS}

This research done on SME se Kecamatan Rengat. The population in this research is Consumers who shop on the Object of the SMES in the study the researcher which amounted to a total 6.642 People. the researchers only took samples by using the method of accidental sampling randomly using the formula Slovin. Then obtained a sample of 99 people consumers. Data collection techniques used were interviews, observation and questionnaires. In the analysis of the data used using multiple linear regression, to find out how big the influence between variables and using $\mathrm{F}$ test and $\mathrm{t}$ test to determine the effect of simultaneous and partial.

\section{RESULT AND DISCUSSION}

To determine the effect of independent variables on Consumer Purchase Decision Business Chips Onion/Banana testing the Hypothesis by using some statistical analysis. From the results of data processing, the obtained regression coefficient and can be seen in the following table:

Table 1 : Regression Coefficient

\begin{tabular}{|l|r|r|r|r|r|}
\hline Variable & \multicolumn{2}{|c|}{$\begin{array}{c}\text { Undstandardized. } \\
\text { Coefficients }\end{array}$} & $\begin{array}{c}\text { standardized } \\
\text { coefficients }\end{array}$ & \multirow{2}{*}{ T } & \multirow{2}{*}{ Sig. } \\
\cline { 2 - 4 } & \multicolumn{1}{|c|}{ B } & Std. Error & \multicolumn{1}{c|}{ Beta } & & \\
\hline (Constant) & 7,431 & 2,657 & & 2,797 &, 006 \\
\hline Product &, 345 &, 113 &, 289 & 3,053 &, 003 \\
\hline Promotion &, 307 &, 088 &, 321 & 3,500 &, 001 \\
\hline
\end{tabular}

Source : Processed Data IBM SPSS Version 21.0

From the above results obtained the formula of the multiple linear regression $Y=7,431+0,345 X 1+0,307 X 2$. That where this study showed a positive relationship between each independent variable against the bound. Partial test results seem that significant product and promotion of $<0.05$. Thus products and promotions in a partial influence on purchase decisions. To see the effect of the variable product and promotion can be seen in the table below :

Table 2 : The ANOVA Table

\begin{tabular}{|l|c|c|c|c|c|}
\hline Model & $\begin{array}{c}\text { Sun Of } \\
\text { Squares }\end{array}$ & Df & $\begin{array}{c}\text { Mean } \\
\text { Square }\end{array}$ & F & Sig. \\
\hline
\end{tabular}


International Journal Of Science, Technology \& Management

\begin{tabular}{|ll|r|r|r|r|r|}
\hline 1 & Regression & 88.374 & 2 & 44.187 & 11.677 & $.000^{\mathrm{b}}$ \\
& Residual & 363.263 & 96 & 3.784 & & \\
& Total & 451.636 & 98 & & & \\
\hline
\end{tabular}

Source : Processed Data IBM SPSS Version 21.0

From the above table it can be seen that sig $<0.05$, the thus products and promotions simultaneously significantly influence the purchase decision. In addition, the level of relationship between all independent variables on the dependent variable in this study is in the criteria of closeness of the relationship of moderate or medium impact and contribution of the influence of independent variable i.e., 19,6\%, while the rest amounted to $80.4 \%$ influenced by other variables not examined in this study.

\section{CONCLUSION}

Based on a study conducted by researchers, product is partially significant effect on purchase decision, so it is with the promotion of the partially significant effect on purchase decision. Together these two variables product and promotion influence on purchase decisions. The promotion has an influence that is more dominant to the purchase decision when compared with the product in research conducted.

\section{REFERENCES}

[1] Sumarwan, Ujang. 2003. Perilaku Konsumen : Teori dan Penerapannya dalam. Pemasaran, Cetakan Pertama. Ghalia Indonesia. Jakarta.

[2] Sutisna. 2003. Perilaku Konsumen dan Komunikasi Pemasaran, Cetakan Ketiga. PT. Remaja Rosdakarya. Bandung.

[3] Kotler, Philip dan Amstrong, Gary. 2004. Marketing an introduction, $7^{\text {th }}$ edition International Edition. Prentice Hall International, Inc, New York.

[4] Buchari, Alma. 2009. Manajemen Pemasaran dan Pemasaran Jasa, Cetakan kedelapan. Alfabeta. Bandung.

[5] Tjiptono, Fandy. 2008. Strategi Pemasaran, Edisi 3. ANDI. Yogyakarta.

[6] Hermanto, H. Pengaruh Persaingan dan Harga terhadap Keputusan Pembelian Sepeda Motor pada CV. Greentech Belilas Kabupaten Indragiri Hulu. Jmbi 2018, 7, 54-63.

[7] Hermanto, H.; Corrina, F.; Supriyadi, A. Faktor - Faktor Yang Mempengaruhi Keputusan Pembelian dan Dampaknya pada Kelangsungan Usaha Mikro Kecil Menengah pada Usaha Fotocopy Sekecamatan Rengat. Jmbi 2019, 8, 328-341.

[8] Hermanto, H. Pengaruh Produk dan Kepuasan Konsumen terhadap Keputusan Pembelian pada PT. Alfa Scorpii Pematang Reba. Jmbi 2018, 7, 106-113.

[9] Apriansyah, R. Pengaruh Kualitas Pelayanan dan Promosi terhadap volume penjualan pada PT. Prioritas Rengat. Jmbi 2018, 7, 37-45.

[10] Kotler, Philip and Kevin Lane Keller. 2011. Manajemen Pemasaran, Edisi 13 Jilid 1 dan 2, Alih Bahasa : Bob Sabran. Erlangga. Jakarta.

[11] Mowen, J.C. and Minor, M. 2002. Perilaku Konsumen. Alih bahasa: Dwi Kartini Yahya. Erlangga. Jakarta. 
International Journal Of Science, Technology \& Management

[12] Dharmaresta, Basu Swastha dan Ibnu Sukotjo. 2013. Pengantar Bisnis Modern, Edisi Ketiga. Liberty. Yogyakarta.

[13] Lovelock, Christopher., Jochen Wirtz, Jacky Mussry. 2014. Pemasaran Jasa, Edisi 7, Jilid 2. Erlangga. Jakarta.

http://ijstm.inarah.co.id 